\title{
The AP-1/NF-kB double inhibitor SP100030 can revert muscle wasting during experimental cancer cachexia
}

\author{
RODRIGO MOORE-CARRASCO ${ }^{2}$, SÍLVIA BUSQUETS ${ }^{1}$, VANESSA ALMENDRO ${ }^{1}$, \\ MOORTHY PALANKI ${ }^{3}$, FRANCISCO J. LÓPEZ-SORIANO ${ }^{1}$ and JOSEP M. ARGILÉS ${ }^{1}$ \\ ${ }^{1}$ Departament de Bioquímica i Biologia Molecular, Universitat de Barcelona, Barcelona, Spain; \\ ${ }^{2}$ Departamento de Bioquímica Clínica e Inmunohematología, Universidad de Talca, \\ Talca, Chile; ${ }^{3}$ Celgene, 4550 Towne Centre Court, San Diego, CA 92121, USA
}

Received November 23, 2006; Accepted January 22, 2007

\begin{abstract}
Daily treatment of rats bearing the cachectic Yoshida $\mathrm{AH}-130$ ascites hepatoma with the double inhibitor of NF-kB and AP-1 SP100030 at a dose of $1 \mathrm{mg} / \mathrm{kg}$ of body weight resulted in a clear amelioration of the cachectic effect, especially at the level of skeletal muscle. Thus, tumour-bearing rats treated with SP100030 showed a significant recovery in the weights of gastrocnemius, EDL, tibialis and cardiac muscles. In addition, treatment with the inhibitor affected both liver and kidney weights. The amelioration in muscle weight was accompanied by an increase in MyoD gene expression, the main transcription factor of muscle tissue involved in muscle differentiation, in gastrocnemius muscle. At the dose used in this study, SP100030 was an effective inhibitor of AP-1; however, the NF-кB transcription factor was not affected. The effects of the inhibitor seem to be at the level of proteolysis since lower total proteolytic rates were found when incubating isolated rat muscles in the presence of SP100030. The inhibitor influenced the gene expression of the ubiquitinconjugating enzyme $\mathrm{E} 2{ }_{14 \mathrm{~K}}$ in skeletal muscle of tumourbearing rats; this enzyme seems to be the main regulator of the activity of the main proteolytic system involved during cancer cachexia, the ubiquitin-proteasome system. In conclusion, treatment of cachectic tumour-bearing rats with SP100030 results in an amelioration of the muscle wasting effect, suggesting that the AP-1 signaling cascade plays an important role in the signaling of muscle wasting associated with disease.
\end{abstract}

Correspondence to: Professor Josep M. Argilés, Cancer Research Group, Departament de Bioquímica i Biologia Molecular, Facultat de Biologia, Universitat de Barcelona, Diagonal 645, 08028 Barcelona, Spain

E-mail: argiles@porthos.bio.ub.es

Key words: SP100030, AP-1, nuclear factor-кB, skeletal muscle, cachexia

\section{Introduction}

Malignant neoplasms frequently induce a progressive loss of lean body mass in the host, associated with marked alterations in endocrine and metabolic homeostasis. Skeletal muscle tissue, which accounts for almost half of the whole body protein mass, is severely affected in cancer cachexia (1-3). Muscle wasting in cachexia is associated with enhanced protein turnover rates $(4,5)$. In addition, cachexia tends to develop at rather late stages of neoplastic disease. Thus, preventing muscle wasting in cancer patients is of great potential clinical interest.

The Yoshida AH-130 rat ascites hepatoma is a suitable model system for studying the mechanisms involved in the establishment of cachexia. Its growth in the host causes rapid and progressive loss of body weight and tissue wasting, particularly in skeletal muscle. Acceleration of tissue protein breakdown accounts for most of the wasting in $\mathrm{AH}-130$ bearers. In particular, skeletal muscle hypercatabolism involves hyperactivation of the ATP-ubiquitin-dependent proteolytic system $(6,7)$. Detectable plasma levels of tumour necrosis factor- $\alpha$ (TNF) and perturbations in hormonal homeostasis $(4,8)$ may play an important role in forcing metabolic balance towards the catabolic side.

Several cytokines have been shown to mimic many of the metabolic abnormalities found in the cancer patient during cachexia. Administration of TNF to rats results in an increased skeletal muscle proteolysis associated with an increase in both gene expression and higher levels of free and conjugated ubiquitin $(4,9,10)$. Other cytokines such as IL- 1 or IFN- $\gamma$ are also able to activate ubiquitin gene expression (11-15). Therefore, TNF [alone or in combination with other cytokines (16-20)] seems to mediate most of the changes concerning nitrogen metabolism associated with cachectic states. In addition to the massive muscle protein loss, during cancer cachexia, similarly to what is observed in skeletal muscle of chronic heart failure patients suffering from cardiac cachexia (21), muscle DNA fragmentation is increased and, thus, apoptosis (22). TNF can mimic the apoptotic response in muscle of healthy animals (23).

In order to define successful approximations for the pharmacological treatment of cachexia, a good knowledge 
of the different intracellular signaling pathways linked to the muscle wasting process is essential. This is especially important since a plethora of mediators, both humoural and tumoural, that have been proposed as being responsible for the muscle protein abnormalities found in cachexia. From this point of view it is interesting to note that previous studies have shown an involvement of both NF-кB and AP-1 signaling cascades during sepsis (24). In COPD patients, with evident muscle wasting, NF-кB has also been proposed as being involved in skeletal muscle (25). In an interesting investigation, Cai et al concluded, using an ІкB kinase beta transgenic model, that $\mathrm{NF}-\kappa \mathrm{B}$ has a marked role in muscle wasting (26). The SP100030 compound has previously been used in pre-clinical studies involving arthritis (27), and hostversus-graft disease (28).

Bearing all this in mind, the main objective of the present study was to test if blockage of the two transcription factors, $\mathrm{NF}-\kappa \mathrm{B}$ and AP-1, was able to interfere with muscle wasting in cachectic tumour-bearing rats. Therefore, we used a double NF-кB and AP-1 inhibitor, SP100030, and examined the effects on the tumour growth and cachexia generated by the rat Yoshida AH-130 ascites hepatoma.

\section{Materials and methods}

Animals. Male Wistar rats (Interfauna, Barcelona, Spain), of 5 weeks of age, were used in the experiment. The animals were maintained at $22 \pm 2^{\circ} \mathrm{C}$ with a regular light-dark cycle (light on from 08:00 a.m. to 08:00 p.m.) and had free access to food and water. The food intake was measured daily. All animal manipulations were made in accordance with the European Community guidelines for the use of laboratory animals.

Tumour inoculation and treatment. Rats were divided into two groups, controls and tumour hosts. The latter received an intraperitoneal inoculum of $10^{8} \mathrm{AH}-130$ Yoshida ascites hepatoma cells obtained from exponential tumours (29). Both tumour and non-tumour bearing animals were subdivided into two groups according to treatment. The treated groups were injected subcutaneously with a daily dose of SP100030 ( $1 \mathrm{mg} / \mathrm{kg}$ body weight) dissolved in $1 \%$ carboxymethyl cellulose (carrier). The non-treated groups received an equivalent injection of the carrier. On day 7 after tumour transplantation, the animals were weighed and anesthetized with an i.p. injection of ketamine/xylazine mixture (3:1) (Imalgene ${ }^{\circledR}$ and Rompun ${ }^{\circledR}$, respectively). The tumour was harvested from the peritoneal cavity and its volume and cellularity evaluated. Tissues were rapidly excised, weighed, and frozen in liquid nitrogen.

Muscle preparations and incubations. The dissection, isolation and incubation of the extensor digitorum longus (EDL) muscles was carried out in rats under ketamine/xylazine mixture anesthesia as previously described $(30,31)$. The muscles were preincubated for $60 \mathrm{~min}$ : $30 \mathrm{~min}$ in Krebs-Henseleit buffer and $30 \mathrm{~min}$ in supplemented medium containing $10^{-4}$ M SP100030 or none, and then incubated for $120 \mathrm{~min}$ in fresh supplemented medium. Total protein degradation by the isolated muscles was calculated as the rate of tyrosine released in the last $2 \mathrm{~h}$ of incubation into the medium in the presence of $0.5 \mathrm{mM}$ cycloheximide in order to block the reincorporation of tyrosine into tissue protein. Tyrosine was measured fluorimetrically as previously described (32).

Electrophoretic mobility shift analysis (EMSA). Nuclear protein extracts from gastrocnemius muscle were isolated as reported previously (33), and protein concentration was determined by BCA protein assay kit (Pierce, USA). Oligonucleotide corresponding to the consensus sequence to nuclear factor- $\mathrm{\kappa} B$ $(\mathrm{NF}-\mathrm{\kappa B})$ and activating protein-1 (AP-1) were end-labeled using $\left[\alpha^{32} \mathrm{P}\right] \mathrm{dCTP}$ and Klenow enzyme (34). The double stranded oligonucleotides end-labeled $(30,000 \mathrm{cpm})$ were incubated for $10 \mathrm{~min}$ on ice with $150 \mu \mathrm{g}$ of nuclear protein extract. Reactions were carried out in a final volume of $20 \mu \mathrm{l}$ containing 12\% glycerol, $12 \mathrm{mM}$ hepes ( $\mathrm{pH} 7.9), 4 \mathrm{mM}$ Tris$\mathrm{HCl}(\mathrm{pH} 7.9), 1 \mathrm{mM}$ EDTA (pH 8.0), $1 \mathrm{mM}$ dithiothreitol (DTT), $25 \mathrm{mM} \mathrm{KCl,} 5 \mathrm{mM} \mathrm{MgCl}_{2}, 40 \mu \mathrm{g} / \mathrm{ml}$ poly dI-dC (deoxyinosinic-deoxycytidylic acid) and protease inhibitors (PMSF, aprotinin and leupeptin). At the end of the incubation, mix samples were electrophoresed at $4^{\circ} \mathrm{C}$ at $325 \mathrm{~V}$ for $60-80 \mathrm{~min}$ on a $7 \%$ non-denaturing polyacrylamide gel in 0.5X Tris-borate-EDTA. After electrophoresis, the gel was dried for $120 \mathrm{~min}$ in a BioRad gel dryer and exposed overnight to X-ray sensitive film (Hyperfilm-MP, Amersham Biosciences) at $-80^{\circ} \mathrm{C}$ with intensifying screens. The specificity of the NF- $\mathrm{KB}$ and $\mathrm{AP}-1$ bands has been confirmed by reactions with mutant end-labeled oligonucleotides $(24,33)$.

RNA isolation and Northern blot analysis. Total RNA from gastrocnemius muscle was extracted using the acid guanidinium isothiocyanate/phenol/chloroform method (35). RNA samples $(20 \mu \mathrm{g})$ were denaturated, subjected to electrophoresis in $1.2 \%$ agarose gels containing $6.3 \%$ formaldehyde and transferred to Hybond $\mathrm{N}$ membranes (Amersham). RNA was fixed to membrane by Genelinker. The RNA in gels and in filters was visualized with ethidium bromide and photographed by UV transillumination to ensure the integrity of RNA, to check the loading of equivalent amounts of RNA and to confirm proper transfer. RNA was transferred in 20X standard saline citrate (SSC; $0.15 \mathrm{M} \mathrm{NaCl}$ and $15 \mathrm{mM}$ sodium citrate, $\mathrm{pH} 7.0$ ). Hybridization was performed at $65^{\circ} \mathrm{C}$ overnight in the hybridization buffer $\left(0.25 \mathrm{M} \mathrm{Na}_{2} \mathrm{HPO}_{4} / 7 \% \mathrm{SDS} / 1 \mathrm{mM}\right.$ EDTA/ $1 \% \mathrm{BSA})$, and denatured labeled probes $\left(10^{6}-10^{7} \mathrm{cpm} / \mathrm{ml}\right)$ were added. Radiolabeled probes were prepared by the random primer method (Amersham). The ubiquitin probe used was a cDNA clone containing 12 pairs of the second ubiquitin coding sequence plus a complete third and fourth ubiquitin coding sequence and 120 base pairs of the $3^{\prime}$ untranslated region of the chicken polyubiquitin gene UBI (36). The membranes were also hybridized with a cDNA probe encoding ubiquitin-conjugating enzyme E2 ${ }_{14 \mathrm{~K}}$ (provided by Dr S.S. Wing, Protein and Polypeptide Hormone Laboratory, Quebec, Canada). Filters were exposed to Hyperfilm-MP (Amersham) at $-80^{\circ} \mathrm{C}$ for $1-4$ days and the films quantified by scanning densitometry.

Biochemicals. The biochemicals were reagent grade and obtained either from Roche S.A. (Barcelona, Spain) or from Sigma Chemical Co. (St. Louis, MO, USA). SP100030 was kindly provided by Moorthy Palanki (Celgene, San Diego, CA, USA). 
Table I. Effects of SP100030 on food intake, body and tissue weight in rats bearing the Yoshida AH-130 ascites hepatoma.

\begin{tabular}{|c|c|c|c|c|}
\hline & $\mathrm{C}(11)$ & CT (12) & $\mathrm{T}(10)$ & TT (12) \\
\hline \multicolumn{5}{|l|}{ Body weight and food intake } \\
\hline Inicial body weight (g) & $134 \pm 3$ & $134 \pm 2$ & $138 \pm 3$ & $135 \pm 2$ \\
\hline Final body weight $(\mathrm{g})$ & $175 \pm 5$ & $172 \pm 3$ & $128 \pm 4^{\mathrm{c}}$ & $129 \pm 4^{\mathrm{c}}$ \\
\hline Body weight increase (g) & $30 \pm 2$ & $29 \pm 2$ & $-6 \pm 2^{c}$ & $-5 \pm 2^{c}$ \\
\hline Carcass (g) & $97 \pm 2$ & $94 \pm 1$ & $70 \pm 2^{c}$ & $77 \pm 3^{c}$ \\
\hline Total food intake $(\mathrm{g})$ & $120 \pm 2$ & $125 \pm 1^{\mathrm{d}}$ & $95 \pm 1^{\mathrm{c}}$ & $109 \pm 5^{\mathrm{a}, \mathrm{d}}$ \\
\hline \multicolumn{5}{|l|}{ Muscle weights } \\
\hline Tibialis (mg) & $212 \pm 4$ & $201 \pm 4$ & $152 \pm 5^{\mathrm{c}}$ & $175 \pm 10^{\mathrm{a}, \mathrm{d}}$ \\
\hline EDL (mg) & $49 \pm 1$ & $47 \pm 1$ & $34 \pm 2^{c}$ & $43 \pm 3^{\mathrm{d}}$ \\
\hline Gastrocnemius (mg) & $685 \pm 18$ & $661 \pm 17$ & $500 \pm 23^{c}$ & $586 \pm 31^{\mathrm{a}, \mathrm{d}}$ \\
\hline Soleus (mg) & $40 \pm 2$ & $42 \pm 2$ & $32 \pm 2^{b}$ & $34 \pm 1^{b}$ \\
\hline \multicolumn{5}{|l|}{ Adipose tissue weights } \\
\hline WAT (mg) & $821 \pm 56$ & $960 \pm 85$ & $408 \pm 61^{\mathrm{c}}$ & $513 \pm 70^{c}$ \\
\hline $\mathrm{BAT}(\mathrm{mg})$ & $224 \pm 27$ & $240 \pm 23$ & $113 \pm 13^{b}$ & $166 \pm 25^{\mathrm{a}}$ \\
\hline \multicolumn{5}{|l|}{ Organ weights } \\
\hline Liver (mg) & $5435 \pm 146$ & $5413 \pm 129$ & $4680 \pm 218^{a}$ & $5044 \pm 162$ \\
\hline Heart (mg) & $416 \pm 12$ & $422 \pm 11$ & $315 \pm 7^{\mathrm{c}}$ & $362 \pm 10^{\mathrm{c}, \mathrm{f}}$ \\
\hline Kidneys (mg) & $523 \pm 13$ & $509 \pm 14$ & $353 \pm 14^{c}$ & $427 \pm 18^{\mathrm{c}, \mathrm{e}}$ \\
\hline Spleen (mg) & $379 \pm 15$ & $395 \pm 22$ & $317 \pm 30$ & $320 \pm 32^{\mathrm{a}}$ \\
\hline \multicolumn{3}{|l|}{ Tumour cell content } & $4343 \pm 354$ & $4031 \pm 362$ \\
\hline \multicolumn{5}{|c|}{$\begin{array}{l}\text { Data are means } \pm \text { SEM with the number of animals indicated in parentheses. Tissue and organ weights are expressed as mg per } 100 \mathrm{~g} \text { initial } \\
\text { body weight }(\mathrm{BW}) \text {. Bilateral tissues are the average of the two. Carcass basically represents muscle, skin and bone. In tumour-bearers, body } \\
\text { weight represents total body weight minus tumour mass. Tumour cell content is expressed in millions of cells. Statistical significance of the } \\
\text { results (Student's t-test): Control vs. tumour: }{ }^{\mathrm{a}} \mathrm{p} \leq 0.05 ;{ }^{\mathrm{b}} \mathrm{p} \leq 0.01 ;{ }^{\mathrm{c}} \mathrm{p} \leq 0.001 \text { and treatment vs. none: }{ }^{\mathrm{d}} \mathrm{p} \leq 0.05 ;{ }^{\mathrm{e}} \mathrm{p} \leq 0.01 ;{ }^{\mathrm{f}} \mathrm{p} \leq 0.001 \text {. Experimental } \\
\text { groups: } \mathrm{C} \text {, control non-treated; CT, control treated; T, tumour-bearing non-treated; TT, tumour-bearing treated. WAT, white adipose tissue; } \\
\text { BAT, brown adipose tissue; EDL, extensor digitorum longus. }\end{array}$} \\
\hline
\end{tabular}

Statistical analysis. Statistical analysis of the data was performed by means of the Student's t-test.

\section{Results and Discussion}

Epidemiological data indicate that cachexia affects at least $30 \%$ of the patients who died of advanced cancer and that it is responsible for the death of at least $22 \%$ of cancer patients $(37,38)$. It is a complex syndrome characterized by weight loss, anorexia and profound disturbances in metabolism which inflict serious muscle wasting. Several experimental models have been used to study muscle wasting during cancer. The rat Yoshida AH-130 ascites hepatoma is a suitable model system to study the mechanisms involved in the establishment of cachexia. The growth causes in the host a rapid and progressive loss of body weight and tissue waste, particularly in skeletal muscle (29). Unfortunately, there seems to be a plethora of mediators involved in the activation of muscle protein degradation during cancer cachexia. Thus, several tumour compounds have been proposed as activators of protein breakdown. Proteolysis-inducing Factor (PIF) was repoted involved in the activation of muscle wasting in an experimental mouse model of cancer cachexia (39). Additionally, cytokines, TNF and IL-6 in particular, have been reported to have a role in wasting in skeletal muscle during cancer $(4,16,17,31,40-44)$. Changes in hormone concentrations and/or sensitivity (insulin-glucocorticoids) may also be involved in wasting (45). Therefore, the design of an effective therapeutic strategy is rather complicated due to the number of different mediators.

Considering the above, it could be more effective to see if therapeutic strategies may be directed to an intracellular common target, since some of the compounds mentioned seem to share similar intracellular signaling pathways. However, few studies have considered the intracellular signaling pathways associated with muscle wasting. Penner et al reported that during experimentally-induced sepsis there was an activation of both NF- $\mathrm{KB}$ and AP-1 signaling pathways (24). In humans, muscle wasting associated with the chronic obstructive pulmonary syndrome (COPD) seems to be associated with activation of $\mathrm{NF}-\kappa \mathrm{B}$ associated with degradation of $\mathrm{I}-\kappa \mathrm{B} \alpha(25)$.

Previous results indicate that NF- $\kappa \mathrm{B}$ is involved in the intracellular actions of PIF, one of the main tumoural compounds involved in cancer cachexia (46). In addition, results from our laboratory indicate that in experimental cancer cachexia there is an activation of AP-1 associated with the process of muscle wasting (47). Therefore, we decided to 
A.
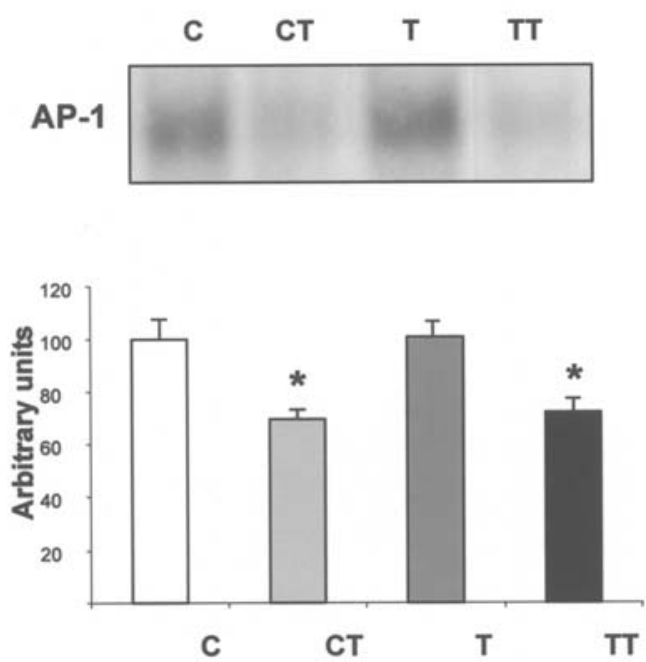

B.
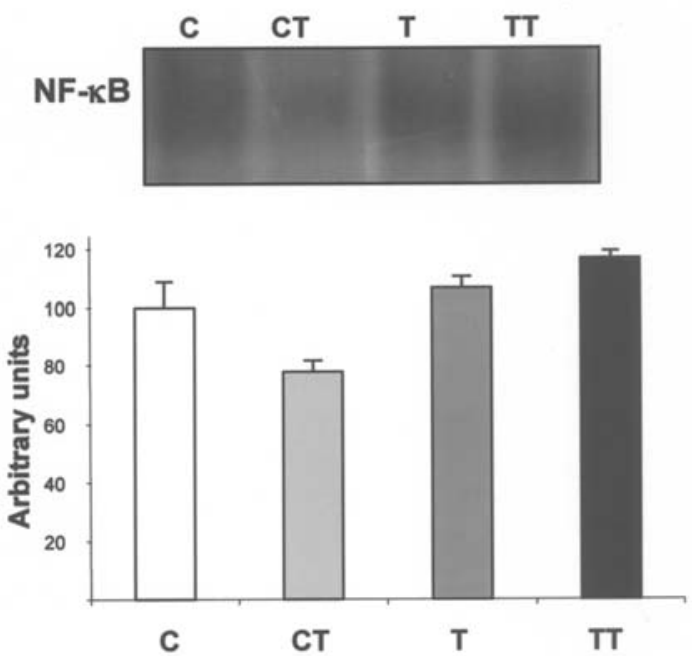

Figure 1. Effects of SP100030 on the NF-кB and AP-1 binding activity in rat gastrocnemius muscle of rats bearing the Yoshida AH-130 ascites hepatoma. (A) Representative EMSA gel. (B) Quantitative representation of the results. For more details, see Materials and methods. Binding activity was assessed by EMSA. Results are means \pm SEM for a minimum of 5 animals per group. Statistical significance of the results (Student's t-test): treatment vs. none: ${ }^{*} \mathrm{p} \leq 0.05$. $\mathrm{C}$, control non-treated; CT, control treated; T, tumour-bearing non-treated; TT, tumour-bearing treated.

A

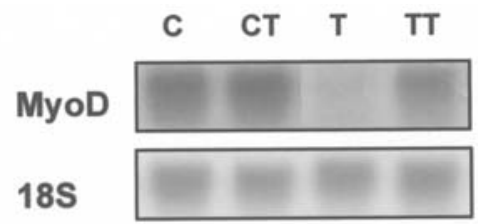

B

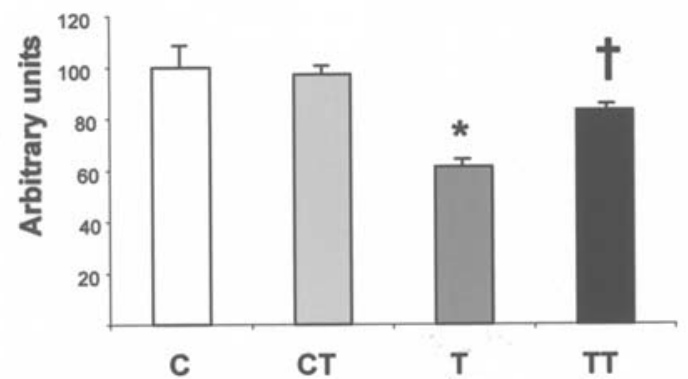

Figure 2. Effects of SP100030 on MyoD gene expression in gastrocnemius muscle of rats bearing the Yoshida AH-130 ascites hepatoma. (A) Representative Northern blots. (B) Quantitative representation of the results. For more details, see Materials and methods. Results are means \pm SEM for a minimum of 5 animals per group. Statistical significance of the results (Student's t-test): Control vs. tumour: ${ }^{*} \mathrm{p} \leq 0.05$ and treatment vs. none: ${ }^{\dagger} \mathrm{p} \leq 0.05$. $\mathrm{C}$, control non-treated; CT, control treated; T, tumour-bearing non-treated; TT, tumour-bearing treated.

investigate if blockage of both $\mathrm{NF}-\kappa \mathrm{B}$ and AP-1 signaling cascades could be an effective therapeutic approach for the treatment of cancer cachexia.

The results presented in Table I show the adequacy of the Yoshida AH-130 ascites hepatoma for studies concerning experimental cancer cachexia. The implantation of the

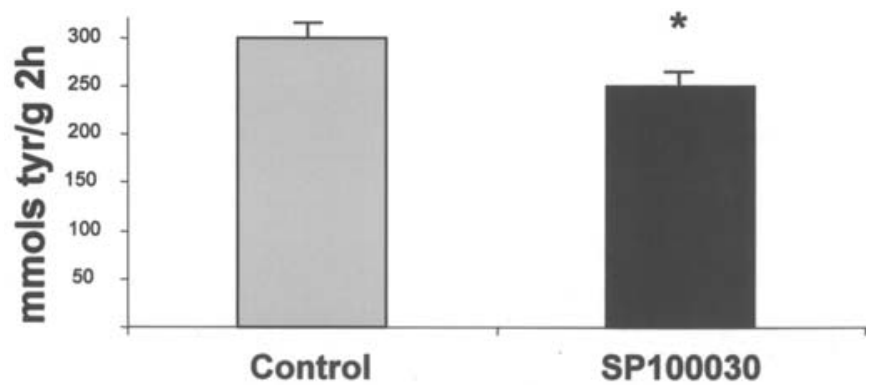

Figure 3. Effects of SP100030 on the total proteolytic rate in isolated rat EDL muscles. Isolated EDL muscles in tension were incubated for a period of $2 \mathrm{~h}$ in the absence or presence of the inhibitor. For more details, see Materials and methods. Proteolytic rates were measured in the presence of cycloheximide $(0.5 \mathrm{mM})$ and are expressed as nmoles tyrosine per $\mathrm{g}$ and $2 \mathrm{~h}$. Results are means \pm SEM for the 10 EDL per group. Statistical significance of the results (Student's t-test): treatment vs. none: ${ }^{*} \mathrm{p} \leq 0.05$.

tumour results in considerable body weight loss (27\%) which is accompanied by a marked decrease in food intake $(21 \%)$. As can be seen in Table I, muscle weights are particularly affected by tumour burden with significant decreases: gastrocnemius $(27 \%)$, soleus (20\%), EDL (31\%) and tibialis $(28 \%)$. In addition, there is a significant decrease in heart $(24 \%)$, kidneys $(33 \%)$ and liver (14\%) weights. At the level of adipose tissue, the presence of the tumour also results in a considerable decrease in both white $(50 \%)$ and brown $(50 \%)$ fat depots. Of note, treatment with the SP100030 inhibitor resulted in amelioration of the weight loss for most of the muscles studied (gastrocnemius, tibialis and EDL). In addition, the heart weight was affected by the treatment, since there was a significant increase in the weight of this organ in relation with the tumour-bearing non-treated group (Table I). Weight loss amelioration was also observed in the kidneys. 
A.
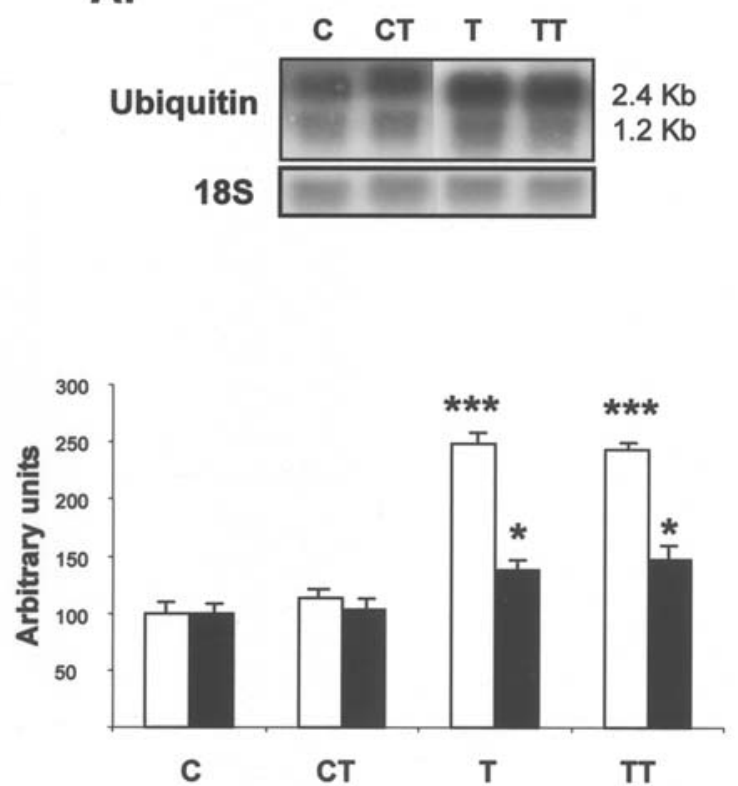

B.
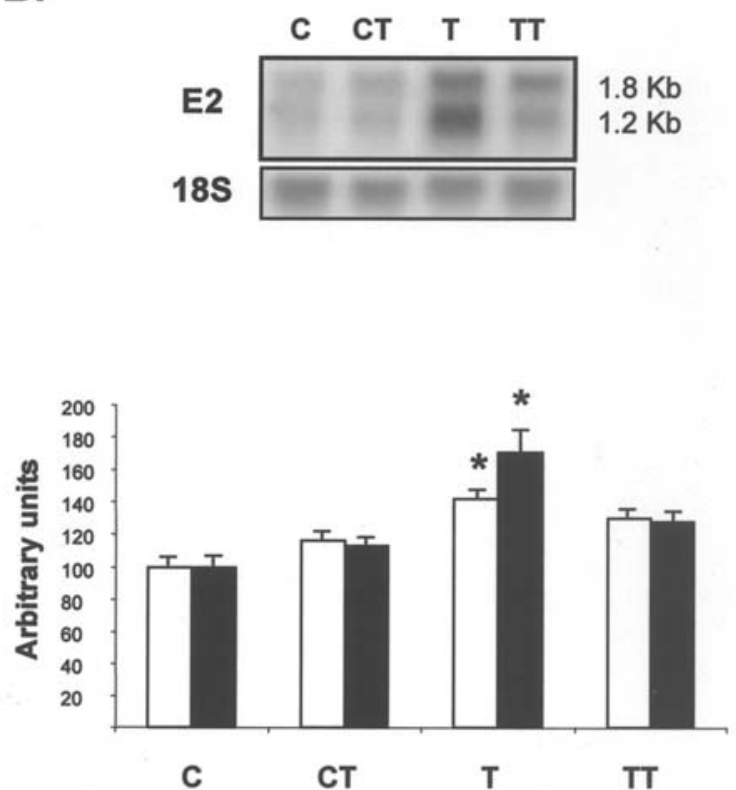

Figure 4. Effects of SP100030 on the gene expression of ubiquitin and the ubiquitin-conjugating enzyme E2 $2_{14 \mathrm{~K}}$ in gastrocnemius muscle of rats bearing the Yoshida AH-130 ascites hepatoma. (A) Representative Northern blots. (B) Quantitative representation of the results. For more details, see Materials and methods. Results are means \pm SEM for a minimum of 5 animals per group. Statistical significance of the results (Student's t-test): Control vs. tumour: ${ }^{*} \mathrm{p} \leq 0.05 ;{ }^{* * *} \mathrm{p} \leq 0.001$. C, control non-treated; CT, control treated; T, tumour-bearing non-treated; TT, tumour-bearing treated.

All of these changes inflicted by the inhibitor treatment were not reflected in total animal weight; however, a tendency for carcass (basically bone and muscle) to increase was observed, although statistical significance was not reached (Table I). The inhibitor treatment resulted in an increase in food intake (5 and 15\% for control treated and tumour treated, respectively), this factor possibly contributing to the observed effects of the treatment upon amelioration of muscle weight loss. It should be noted that the inhibitor treatment did not inflict any changes in tumour growth, as presented in Table I.

Previous studies have shown that SP100030 behaves as an effective double inhibitor of both NF-кB and AP-1 (48). We decided to test whether this was the case in our experimental set-up and, therefore, we performed an electrophoretic mobility shift assay (EMSA) of the muscle samples and found that, while an effective inhibition of AP-1 (30 and 29\% for control and tumour-bearing, respectively) was present, NF-кB did not seem to be altered (Fig. 1). Different in vivo studies have shown the efficacy of the inhibitor for both transcription factors but using much higher doses $(10-20 \mathrm{mg} / \mathrm{kg}$ bw) $(27,28,48,49)$ than the one we used $(1 \mathrm{mg} / \mathrm{kg} \mathrm{bw})$. We decided to use this dose to minimize the toxic effects of the inhibitor.

The treatment with the inhibitor also resulted in changes in MyoD transcription factor in gastrocnemius muscles of tumour-bearing rats, as shown in Fig. 2. In the tumourbearing rats, SP100030 treatment resulted in amelioration of the effect of tumour burden on muscle MyoD gene expression (Fig. 2). These results are in agreement with the recovery in muscle weights inflicted by the inhibitor treatment during tumour burden (Table I). Treatment with the inhibitor did not affect the control, non-tumour bearing animals.
Taking into consideration the fact that, as we have previously reported during experimental cancer cachexia, muscle proteolysis is the main mechanism that is activated and related with wasting $(6,7,50)$, we decided to investigate if the proteolytic rate was affected or not in the tumour bearing rats. We incubated isolated skeletal muscles in an ex vivo set up, as previously described (30-32), and examined the proteolytic rates in the presence or absence of the inhibitor. The results presented in Fig. 3 show that the SP100030 inhibitor significantly reduces the proteolytic rate in incubated muscles (16\%). These results seem to indicate that at least the AP-1 signaling cascade is involved in the proteolytic events that take place in skeletal muscle during cancer cachexia. Our group has described that the main proteolytic mechanism involved in the increased proteolytic rate found associated with tumour burden was that of the ubiquitin-proteasome system $(6,7,50)$. Bearing this in mind, we investigated if treatment with the inhibitor affected the ubiquitin system by examining the expression of some components of the ubiquitin system. The results presented in Fig. 4 show that, in spite of the fact that the ubiquitin gene expression does not seem to be affected by the treatment, a lack of activation is observed in the ubiquitin-conjugating enzyme $\mathrm{E} 2_{14 \mathrm{~K}}$ in the treated animals. It has to be pointed out here that this enzyme is considered one of the key regulatory proteins that control the activity of the ubiquitin-proteasome system (51-55).

The results presented herein support our previous studies where we have emphasised the important of the AP-1 signaling cascade, as opposed to the NF- $\mathrm{KB}$ one in muscle wasting associated with cancer cachexia. A lack of NF-кB activation was observed in the same experimental model used here (47) and infection of cachectic tumour-bearing animals 
with TAM-67 carrying viruses, a negative dominant of c-jun/ AP-1, results in amelioration of muscle wasting (56). Collectively, the importance of the AP-1 signaling cascade in muscle wasting, at least in experimental cancer cachexia, seems to be very clear. This is important from a therapeutic point of view since this transcription factor seems to be involved in the signaling cascade associated with several cytokines which have been proposed to have a role in cachexia (57). However, future studies are still necessary to improve this potential use of AP-1 inhibitors in preclinical studies involving cancer cachexia.

\section{Acknowledgements}

This work was supported by grants from the Instituto de Salud Carlos III (03/0100) of the Ministerio de Sanidad y Consumo, from the Dirección General de Investigación Científica y Técnica (BFI2002-02186) of the Ministerio de Educación y Ciencia, and from the Generalitat de Catalunya (SGR/00108).

\section{References}

1. Argilés JM, Alvarez B and López-Soriano FJ: The metabolic basis of cancer cachexia. Med Res Rev 17: 477-498, 1997.

2. Studley HO: Percentage of weight loss. A basic indicator of surgical risk in patients with chronic pectic ulcer. JAMA 106: 458-460, 1936.

3. Kern PA and Norton JA: Cancer cachexia. J Parenter Enteral Nutr 12: 286-298, 1988.

4. Costelli P, Carbó N, Tessitore L, Bagby GJ, López-Soriano FJ, Argilés JM and Baccino FM: Tumor necrosis- $\alpha$ mediates changes in tissue protein turnover in a rat cancer cachexia model. J Clin Invest 92: 2783-2789, 1993 .

5. García-Martinez C, López-Soriano FJ and Argilés JM: Amino acid uptake in skeletal muscle of rats bearing the Yoshida $\mathrm{AH}-$ 130 ascites hepatoma. Mol Cell Biochem 148: 17-23, 1995.

6. Llovera M, García-Martínez C, Agell N, López-Soriano FJ and Argilés JM: Muscle wasting associated with cachexia is linked to an important activation of the ATP-dependent ubiquitinmediated proteolysis. Int J Cancer 61: 138-141, 1995.

7. Llovera M, García-Martínez C, Agell N, López-Soriano FJ, Marzabal M and Argilés JM: Ubiquitin gene expression is increased in skeletal muscle of tumour-bearing rats. FEBS Lett 338: 311-318, 1994.

8. Carbó N, Costelli P, Tessitore L, Bagby GJ, López-Soriano FJ, Baccino FM and Argilés JM: Anti-tumour necrosis factor-alpha treatment interferes with changes in lipid metabolism in a tumour cachexia model. Clin Sci 87: 349-355, 1994.

9. Argilés JM, García-Martínez C, Llovera M and López-Soriano FJ: The role of cytokines in muscle wasting: its relation with cancer cachexia. Med Res Rev 12: 637-652, 1992.

10. Garcia-Martinez C, Llovera M, Agell N, Lopez-Soriano FJ and Argiles JM: Ubiquitin gene expression in skeletal muscle is increased during sepsis: involvement of TNF-alpha but not IL-1. Biochem Biophys Res Commun 217: 839-844, 1995.

11. Llovera M, Carbo N, Lopez-Soriano J, Garcia-Martinez C, Busquets S, Alvarez B, Agell N, Costelli P, Lopez-Soriano FJ, Celada A and Argiles JM: Different cytokines modulate ubiquitin gene expression in rat skeletal muscle. Cancer Lett 133: 83-87, 1998.

12. Boes B, Hengel H, Ruppert T, Multhaup G, Koszinowski UH and Kloetzel PM: Interferon gamma stimulation modulates the proteolytic activity and cleavage site preference of $20 \mathrm{~S}$ mouse proteasomes. J Exp Med 179: 901-909, 1994.

13. Aki M, Shimbara N, Takashina M, Akiyama K, Kagawa S, Tamura T, Tanahashi N, Yoshimura T, Tanaka K and Ichihara A: Interferon-gamma induces different subunit organizations and functional diversity of proteasomes. J Biochem 115: 257-269, 1994.

14. Gaczynska M, Rock KL and Goldberg AL: Gamma-interferon and expression of MHC genes regulate peptide hydrolysis by proteasomes. Nature 365: 264-267, 1993.
15. Costelli P, Llovera M, Carbo N, Garcia-Martinez C, Lopez-Soriano FJ and Argiles JM: Interleukin-1 receptor antagonist (IL-1ra) is unable to reverse cachexia in rats bearing an ascites hepatoma (Yoshida AH-130). Cancer Lett 95: 33-38, 1995.

16. Llovera M, Garcia-Martinez C, Lopez-Soriano J, Carbo N, Agell N, Lopez-Soriano FJ and Argiles JM: Role of TNF receptor 1 in protein turnover during cancer cachexia using gene knockout mice. Mol Cell Endocrinol 142: 183-189, 1998.

17. Llovera M, Garcia-Martinez C, Lopez-Soriano J, Agell N, Lopez-Soriano FJ, Garcia I and Argiles JM: Protein turnover in skeletal muscle of tumour-bearing transgenic mice overexpressing the soluble TNF receptor-1. Cancer Lett 130: 19-27, 1998.

18. Llovera M, Garcia-Martinez C, Lopez-Soriano FJ and Argiles JM: The effect of chronic tumour necrosis factor-alpha treatment on urinary nitrogen excretion in the rat. Biochem Mol Biol Int 33: 681-689, 1994.

19. Argiles JM, Costelli P, Carbo N, Pallares-Trujillo J and Lopez-Soriano FJ: Tumour growth and nitrogen metabolism in the host. Int J Oncol 14: 479-486, 1999.

20. Argiles JM, Busquets S and Lopez-Soriano FJ: Cytokines in the pathogenesis of cancer cachexia. Curr Opin Clin Nutr Metab Care 6: 401-406, 2003.

21. Anker SD, Steinborn W and Strassburg S: Cardiac cachexia. Ann Med 36: 518-529, 2004.

22. van Royen M, Carbo N, Busquets S, Alvarez B, Quinn LS, Lopez-Soriano FJ and Argiles JM: DNA fragmentation occurs in skeletal muscle during tumor growth: A link with cancer cachexia? Biochem Biophys Res Commun 270: 533-537, 2000.

23. Carbo N, Busquets S, van Royen M, Alvarez B, Lopez-Soriano FJ and Argiles JM: TNF-alpha is involved in activating DNA fragmentation in skeletal muscle. Br J Cancer 86: 1012-1016, 2002.

24. Penner CG, Gang G, Wray C, Fischer JE and Hasselgren PO: The transcription factors NF-kappab and AP-1 are differentially regulated in skeletal muscle during sepsis. Biochem Biophys Res Commun 281: 1331-1336, 2001.

25. Agusti A, Morla M, Sauleda J, Saus C and Busquets X: NFkappaB activation and iNOS upregulation in skeletal muscle of patients with COPD and low body weight. Thorax 59: 483-487, 2004

26. Cai D, Frantz JD, Tawa NE Jr, Melendez PA, Oh BC, Lidov HG, Hasselgren PO, Frontera WR, Lee J, Glass DJ and Shoelson SE: IKKbeta/NF-kappaB activation causes severe muscle wasting in mice. Cell 119: 285-298, 2004.

27. Gerlag DM, Ransone L, Tak PP, Han Z, Palanki M, Barbosa MS, Boyle D, Manning AM and Firestein GS: The effect of a T cellspecific NF-kappa B inhibitor on in vitro cytokine production and collagen-induced arthritis. J Immunol 165: 1652-1658, 2000.

28. Morikawa M, Shorthouse RA, Suto MJ, Goldman ME and Morris RE: A novel inhibitor of nuclear factor-kappa B and activator protein-1 transcription factors in $\mathrm{T}$ cells suppresses host-versus-graft alloreactivity in vivo. Transplant Proc 29: 1269-1270, 1997

29. Tessitore L, Costelli P, Bonetti G and Baccino FM: Cancer cachexia, malnutrition, and tissue protein turnover in experimental animals. Arch Biochem Biophys 306: 52-58, 1993.

30. Busquets S, Alvarez B, Lopez-Soriano FJ and Argiles JM: Branched-chain amino acids: a role in skeletal muscle proteolysis in catabolic states? J Cell Physiol 191: 283-289, 2002.

31. Llovera M, Garcia-Martinez C, Agell N, Lopez-Soriano FJ and Argiles JM: TNF can directly induce the expression of ubiquitindependent proteolytic system in rat soleus muscles. Biochem Biophys Res Commun 230: 238-241, 1997.

32. Waalkes TP and Udenfriend S: A fluorometric method for the estimation of tyrosine in plasma and tissues. J Lab Clin Med 50: 733-736, 1957.

33. Blough E, Dineen B and Esser K: Extraction of nuclear proteins from striated muscle tissue. Biotechniques 26: 202-206, 1999.

34. Solanes G, Pedraza N, Iglesias R, Giralt M and Villarroya F: Functional relationship between MyoD and peroxisome proliferator-activated receptor-dependent regulatory pathways in the control of the human uncoupling protein-3 gene transcription. Mol Endocrinol 17: 1944-1958, 2003.

35. Chomczynski P and Sacchi N: Single-step method of RNA isolation by acid guanidinium thiocyanate phenol chloroform extraction. Anal Biochem 162: 156-159, 1987.

36. Bond U and Schlesinger MJ: Ubiquitin is a heat-shock protein in chicken embryo fibroblasts. Mol Cell Biol 5: 949-956, 1985. 
37. Warren S: The immediate causes of death in cancer. Am J Med Sci 184: 610-615, 1932.

38. De Wys WD, Begg C, Lavin PT, Band PR, Bennet JM, Bertino JR, Cohen MH, Douglas HO Jr and Engstrom PF: Prognostic effect of weight loss prior to chemotherapy in cancer patiens. Am J Med 69: 491-497, 1980.

39. Todorov PT, Field WN and Tisdale MJ: Role of a proteolysisinducing factor (PIF) in cachexia induced by a human melanoma (G361). Br J Cancer 80: 1734-1737, 1999.

40. DeJong CH, Busquets S, Moses AG, Schrauwen P, Ross JA, Argiles JM and Fearon KC: Systemic inflammation correlates with increased expression of skeletal muscle ubiquitin but not uncoupling proteins in cancer cachexia. Oncol Rep 14: 257-263, 2005.

41. Kwak KS, Zhou X, Solomon V, Baracos VE, Bannon AW, Davis J, Boyle WJ, Lacey DL and Han HQ: Regulation of protein catabolism by muscle-specific and cytokine-inducible ubiquitin ligase E3alpha-II during cancer cachexia. Cancer Res 64: 8193-8198, 2004

42. Costelli P, Bossola M, Muscaritoli M, Grieco G, Bonelli G, Bellantone R, Doglietto GB, Baccino FM and Rossi-Fanelli F: Anticytokine treatment prevents the increase in the activity of ATP-ubiquitin- and $\mathrm{Ca}(2+)$-dependent proteolytic systems in the muscle of tumour-bearing rats. Cytokine 19: 1-5, 2002.

43. Alvarez B, Quinn LS, Busquets S, Quiles MT, Lopez-Soriano FJ and Argiles JM: Tumor necrosis factor-alpha exerts interleukin6-dependent and -independent effects on cultured skeletal muscle cells. Biochim Biophys Acta 1542: 66-72, 2002.

44. Tsujinaka T, Fujita J, Ebisui C, Yano M, Kominami E, Suzuki K, Tanaka K, Katsume A, Ohsugi Y, Shiozaki H and Monden M: Interleukin 6 receptor antibody inhibits muscle atrophy and modulates proteolytic systems in interleukin 6 transgenic mice. J Clin Invest 97: 244-249, 1996.

45. Frost RA and Lang $\mathrm{CH}$ : Skeletal muscle cytokines: regulation by pathogen-associated molecules and catabolic hormones. Curr Opin Clin Nutr Metab Care 8: 255-263, 2005.

46. Smith HJ, Wyke SM and Tisdale MJ: Role of protein kinase C and NF-kappaB in proteolysis-inducing factor-induced proteasome expression in $\mathrm{C}(2) \mathrm{C}(12)$ myotubes. Br J Cancer 90: 1850-1857, 2004.

47. Costelli P, Muscaritoli M, Bossola M, Moore-Carrasco R, Crepaldi S, Grieco G, Autelli R, Bonelli G, Lopez-Soriano FJ, Pacelli F, Argiles JM, Doglietto GB, Baccino FM and Rossi Fanelli F: Skeletal muscle wasting in tumor-bearing rats is associated with MyoD down-regulation. Int J Oncol 26: 1663-1668, 2005.
48. Huang TJ, Adcock IM and Chung KF: A novel transcription factor inhibitor, SP100030, inhibits cytokine gene expression, but not airway eosinophilia or hyperresponsiveness in sensitized and allergen-exposed rat. Br J Pharmacol 134: 10291036, 2001.

49. Goldman ME, Ransone LJ, Anderson DW, Gaarde WA, Suto MJ, Sullivan RW, Shorthouse R, Morikawa M and Morris RE: SP100030 is a novel T-cell-specific transcription factor inhibitor that possesses immunosuppressive activity in vivo. Transplant Proc 28: 3106-3109, 1996.

50. Costelli P, Tullio RD, Baccino FM and Melloni E: Activation of $\mathrm{Ca}(2+)$-dependent proteolysis in skeletal muscle and heart in cancer cachexia. Br J Cancer 84: 946-950, 2001.

51. Li YP, Chen Y, Li AS and Reid MB: Hydrogen peroxide stimulates ubiquitin-conjugating activity and expression of genes for specific E2 and E3 proteins in skeletal muscle myotubes. Am J Physiol Cell Physiol 285: C806-C812, 2003.

52. Fang CH, Sun X, Li BG, Fischer DR, Pritts TA, Penner G and Hasselgren PO: Burn injuries in rats upregulate the gene expression of the ubiquitin-conjugating enzyme E2(14k) in skeletal muscle. J Burn Care Rehabil 21: 528-534, 2000.

53. Yao T and Cohen RE: Cyclization of polyubiquitin by the E2-25K ubiquitin conjugating enzyme. J Biol Chem 275: 36862-36868, 2000.

54. Gonen H, Bercovich B, Orian A, Carrano A, Takizawa C, Yamanaka K, Pagano M, Iwai K and Ciechanover A: Identification of the ubiquitin carrier proteins, E2s, involved in signal-induced conjugation and subsequent degradation of IkappaBalpha. J Biol Chem 274: 14823-14830, 1999

55. Pagano M: Cell cycle regulation by the ubiquitin pathway. FASEB J 11: 1067-1075, 1997.

56. Moore-Carrasco R, García-Martínez C, Busquets S, Ametller E, Barreiro E, López-Soriano FJ and Argilés JM: The AP-1/ cjun signalling cascade is involved in muscle differentiation: implications in muscle wasting during cancer cachexia. FEBS Lett 580: 691-696, 2006.

57. Argiles JM, Busquets S and Lopez-Soriano FJ: The pivotal role of cytokines in muscle wasting during cancer. Int J Biochem Cell Biol 37: 2036-2046, 2005. 